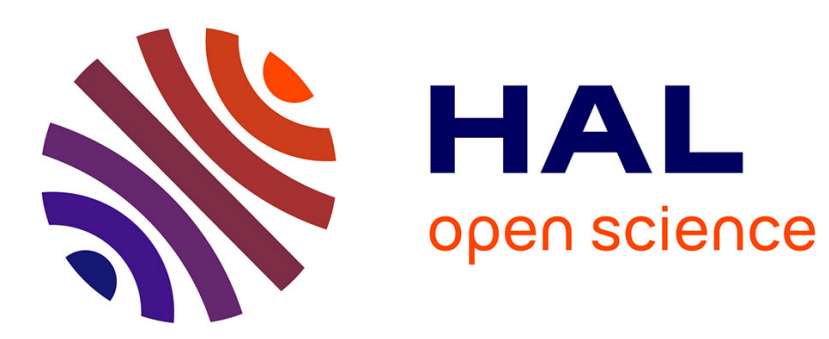

\title{
White bread bio-politics: purity, health, and the triumph of industrial baking
}

Aaron Bobrow-Strain

\section{To cite this version:}

Aaron Bobrow-Strain. White bread bio-politics: purity, health, and the triumph of industrial baking. cultural geographies, 2008, 15 (1), pp.19-40. 10.1177/1474474007085783 . hal-00572013

\section{HAL Id: hal-00572013 \\ https://hal.science/hal-00572013}

Submitted on 1 Mar 2011

HAL is a multi-disciplinary open access archive for the deposit and dissemination of scientific research documents, whether they are published or not. The documents may come from teaching and research institutions in France or abroad, or from public or private research centers.
L'archive ouverte pluridisciplinaire HAL, est destinée au dépôt et à la diffusion de documents scientifiques de niveau recherche, publiés ou non, émanant des établissements d'enseignement et de recherche français ou étrangers, des laboratoires publics ou privés. 


\title{
White bread bio-politics: purity, health, and the triumph of industrial baking
}

\author{
Aaron Bobrow-Strain \\ Politics Department, Whitman College
}

\begin{abstract}
This article traces the massive commodification and industrialization of the USA's single most important food: bread. It argues that bakers overcame serious obstacles to capitalist development during this period thanks to the construction of contingent and contested associations between industrial bread and larger discourses of purity, hygiene, and progress circulating through turn-of-the-century America. It explores two arenas in which this articulation operated: the re-making of baking as a techno-science of expert control and the visual spectacle of streamlined, white loaves. This story, in turn, offers larger lessons about the contradictory politics of food safety in our own time. Building on Michel Foucault's work on bio-politics, it shows how notions of food safety dependent on discourses of purity, contagion, hygiene, and vitality inevitably constitute lines of exclusion and social hierarchy, even as they are used to mobilize 'progressive' social change.
\end{abstract}

Keywords: Bio-politics • bread • commodification • food politics • food safety • Foucault • industrialization

The unconquerable preference of the human stomach for white bread had been triumphantly vindicated. Not merely white bread, but the whitest of white.

Dr Woods Hutchinson, Good Housekeeping Magazine, May 1913

'Diet' itself ... was a fundamental category through which behavior could be conceptualized. It characterized the way in which one managed one's existence, and it enabled a set of rules to be affixed to conduct; it was a mode of problematization of behavior that was indexed to a nature which had to be preserved and to which it was right to conform.

Michel Foucault, The Use of Pleasure

\section{The triumph of industrial white bread}

'To begin then with the very foundation of a good table - Bread: What ought it to be?' Catherine and Harriet Beecher Stowe posed this question in their path-breaking compendium of domestic advice, The American Woman's Home. ${ }^{1}$ The book, which quickly found a place as the essential primer of Victorian domesticity in the USA, promised modern answers to modern problems. Yet, the Beecher sisters' thoughts on bread had a timeless air: 'Bread-making can be cultivated ... as a fine art', guided by 'the divine principle of beauty,' they argued. ${ }^{2}$ 
Less than 50 years later, however, the Beechers' invocation of art and aesthetics as the basis for 'what bread ought to be' had all but vanished from cookbooks and other food writing. Mary D. Warren, one of countless purveyors of domestic advice who followed in the Beechers' footsteps, captured the new spirit of bread. Writing in a 1923 Ladies Home Journal article on 'The science of oven management,' she insisted, 'Modern inventions have made an exact science of baking, and there is no reason whatever for failure ... One simply cannot bake by guesswork and expect to secure results, any more than one can ascertain with certainty a sick person's temperature by merely feeling his brow.' ${ }^{3}$

Thus, by the 1920 s, bread making was widely imagined as a techno-science. Like family health care, baking was to be a terrain of control and expert measurement rather than art and aesthetics. 'Modern baking is scientifically done. Nothing is left to chance,' an elementary school textbook read: 'The baker has studied the principles of baking and understands the working of the laws that govern his product. In his bakery there is a laboratory with microscopes, tubes, balances, and other instruments, the materials to be used are tested by experts ... [The modern baker] is guided by scientific laws. ${ }^{4}$

That discursive shift mirrored phenomenal changes in the production, distribution, and consumption of bread - the culmination of a long process of scientific rationalization, capitalist development, and cultural change. This article examines how that larger process played out between 1890 and 1930. At the beginning of that 40-year period, bread was the country's single most important food and 90 per cent of it was baked in homes by women. By the end of the period, bread was still the country's number one food, but 94 per cent of it was baked outside the home by men. With the exception of a few, mostly rural, households, bread production had been almost entirely displaced from the realm of women's work and the space of the home. ${ }^{5}$ What's more, it was displaced to increasingly large and increasingly distant bakery sites.

In 1890, the country's few commercial bakeries were nearly all one-oven shops with three or fewer employees located within walking distance of their patrons' homes. ${ }^{6}$ Bread was as it had been for millennia - brownish, heterogeneous, and unruly; the product of unstandardized artisan labor and unreliable technology. By 1900, however, the revolution had begun. Between 1850 and 1900 the number of commercial bakeries grew by 700 per cent, far outpacing population growth. By the turn of the century, the country's largest bakeshops could produce 15,000 loaves a day. 'System and order' had 'moulded many small bakeshops into model palaces of automatic baking,' and, by the late 1920s, large bakeries regularly churned out 100,000 loaves a day. ${ }^{7}$ A model bakery erected by the American Bakers' Association at their 1925 meetings in Buffalo was said to have topped one million loaves in 24 hours. 8 Critically, it wasn't just the production of bread that had changed; bread itself had changed. By 1930, bread was uniformly white, sliced, and modern - and Americans loved it.

In short, this is a story of massive commodification and industrialization, and, as with any such story, it is an account of enormously complex cultural change. ${ }^{9}$ This article cannot pretend to capture the full range of social forces, political struggles, and economic impulses swirling around the staff of life during this moment of upheaval. Instead, it focuses on one small, and largely unknown, piece of the making of modern bread: it argues that, as with other foods industrialized during this period, a larger politics of purity, health, and hygiene circulating through early 20th-century America shaped the making of modern bread. ${ }^{10}$ Indeed, 
the baking industry overcame a series of potentially crippling economic and social obstacles to the commodification and industrialization of bread because of the ways in which the new, modern loaves materialized concerns about purity, hygiene, and sanitation. In theoretical terms, what we see is a contingent articulation between bio-political discourses of social purity and the trajectories of capitalist industrialization in the baking industry. This articulation of baking and social purity did not determine the trajectories of bread commodification or singlehandedly cause the triumph of industrial bread - this was a highly overdetermined process of capitalist development - but it did give a particular shape to that process. It also meant that struggles over the staff of life were irrevocably entangled with larger anxieties about racial purity, unprecedented immigration rates, rapid urbanization, and women's changing roles in society that defined this period. ${ }^{11}$

More specifically, this article argues that U.S. bakers overcame a serious problem at the turn of the century: thanks to innovations in bakery technology and science, bakers could produce bread faster and cheaper than ever before, but, at the same time, the increasing accessibility of non-grain foods (e.g. fresh fruits, canned meats) ${ }^{12}$ combined with a deep association of store-bought bread with contamination, adulteration, and poverty threatened to depress overall bread consumption. Bakers needed to convince consumers that bread had a place on the modern American table. By the 1930s, despite lingering unease and criticisms of bakers' bread, that case had been made successfully: industrial white bread was widely associated with purity, health, and progress. This article illuminates two arenas in which this re-making of the symbolic-material life of bread operated:

First, as Section 3 ('Control for Sale') contends, the professionalization of baking and the adoption of specific new technologies (i.e. automatic bread wrapping) repositioned the muchmaligned baking industry as a site of techno-scientific control. This process, emerging in conversation with larger discourses of food safety, national stamina, and social hygiene helped establish bakery bread as a symbol of purity, health, and responsible citizenship.

Second, Section 4 ('The Spectacle of Clean') argues that the highly engineered visual spectacle of industrial bread - its internal and external uniformity, its streamlined shape, and sparkling whiteness - gave the new bread a modern aura. In particular, industrial bread's unprecedented whiteness resonated with newly emerging associations between the color white and purity, cleanliness and social progress.

These are, by no means, the only arenas in which the cultural and economic refiguring of baking played out - indeed, untangling these two themes from the many other intertwined processes at work in early 20th-century baking is almost impossible. It is, however, useful to single out these two themes because, as I discuss at length in Section 2 ('The Bio-politics of Food') and the conclusion, they draw our attention to the bio-political dynamics of diet and food safety debates. This not only adds a critical piece to our knowledge of the political processes through which the U.S. food system became what it is today, ${ }^{13}$ it also places a growing geographical literature that shines a critical light on contemporary food-related activism ${ }^{14}$ into conversation with an important historical literature tracing the bio-politics of public health activism in the early 20th century. ${ }^{15}$ In making this link between the concerns of past and present dietary politics, it offers a cautionary tale for contemporary food safety activism; a warning about the dangers inherent in framing food politics in terms of health, hygiene, and purity. Watershed improvements in food safety were not to be scoffed at in a time when 
food-borne illnesses ranked as leading causes of death in the USA, and even a commodity as innocuous and quotidian as the loaf of bread could cause tremendous anxiety, ${ }^{16}$ but food purity discourses often authorized quiet coercions and reinforced exclusionary politics.

Drawing on the work of Michel Foucault, this article shows how discourses of food safety constitute a form of bio-politics aimed at safeguarding and improving the conditions of life for a defined population. ${ }^{17}$ While bio-political interventions have produced many important reforms - landmark food safety laws, for example - Foucault argues that bio-politics are also inherently bound up in forms of exclusion, hierarchy, and racism aimed at 'fragmenting the field of the biological that power controls." 18 Through its language of health, purity, and hygiene, biopolitics constructs society as a biological domain and takes as its highest goal the identification and elimination of internal and external contagions to that living body. Thus, this article suggests that, when framed in these bio-political terms, food safety activism is ill-suited, and perhaps counterproductive, to the challenges of creating a radically democratic food system. ${ }^{19}$ It also suggests that more attention needs to be paid to the alimentary or dietetic workings of biopolitics; something that Foucault and most subsequent Foucault scholars have overlooked.

\section{The bio-politics of food}

This section provides a general historical-theoretical framing for the specific argument about bread that follows in Sections 3 and 4, showing how Foucault's concept of bio-politics can illuminate the high-stakes nature of struggles over purity and hygiene in early 20th-century America.

Discourses of hygiene, health, and food purity permeated early 20th-century American life. Promoted by temperance advocates, suffragist activists, government officials, advertisers, nativists, and business groups, these discourses emerged from no single point and belonged to no one political perspective. Articulated through advertising, product design, government programs, and school curricula, meticulous attention to the purity and safety of food was constructed as the duty, desire, and moral responsibility of all. This imperative of health and purity produced powerful results ranging from historic food safety legislation, including the watershed 1906 Pure Food, Drink, and Drug Act, to desperately needed sanitary reforms in milk, meat processing, and other food industries. ${ }^{20}$ The baking industry was no different. There, food-purity discourses and activism generated important sanitary reforms - often in the face of organized resistance from bakers themselves.

Michel Foucault's concept of bio-politics allows us to place the story of early 20th-century U.S. food safety concerns in the context of broad processes of social change that saw, 'the emergence of the health and physical well-being of the population in general as one of the essential objectives of political power,' and made 'the imperative of health-at once the duty of each and the objective of all. ${ }^{21}$

For Foucault, bio-politics was a logical extension of power in disciplinary society. While disciplinary technologies could train useful habits into the bodies of docile subjects and distribute those bodies in space to promote maximum efficiency, they could not ensure stamina. Even a population of meticulously disciplined bodies could not sustain its productivity in a state of perpetual sickness. Contagion, disease, and impurity, 'sapped the population's strength, shortened the working week, wasted energy ... cost money,' and, in the words of 
Progressive era pure foods reformer Alfred McCann, augured moral collapse and '[white] race suicide on a colossal scale. ${ }^{22}$

Thus, as statistics and other scientific measures developed during the 18th and 19th centuries allowed the population to be conceived of as a whole, that population increasingly found itself the target of interventions designed to create positive improvements in life and eliminate threats to the health of the population. 'In a word, security mechanisms [had] to be installed around the random element inherent in a population of living beings so as to optimize the state of life. ${ }^{23}$

In this context, the health and well-being of the general population increasingly became one of the most important objects of political power. The new imperative of health operated in several key arenas including: (1) the medicalization of home life with the goal of producing, 'healthy, clean, fit bodi[ies and] purified, cleansed, aerated, domestic space[s]'; (2) the elevation of hygiene to levels of paramount importance; and (3) the close articulation between hygiene and social control. Connections between hygiene and social control appeared particularly evident to Foucault in efforts to rationalize and order urban space against the threat of disease: 'The needs of hygiene demand an authoritarian medical intervention in what are regarded as the privileged breeding grounds of disease: prisons, ships, harbor installations, the hopiteaux generaux where vagabonds, beggars, and invalids mingle together. ${ }^{24}$

Yet, despite the centrality of diet to population vigor and the salience of food production and distribution as potential vector of disease, Foucault does not generally acknowledge food and nutrition as pivotal elements of bio-politics. The one exception to this seems to be a section of The History of Sexuality Volume II: The Use of Pleasure from which this article's epigram was drawn. In that section, Foucault reflects on the Greek conception of dietetics - a mode of caring for the body; of managing existence through the careful regulation food, sleep, sex, and hygiene. This is not the place for a long exegesis of dietetics' relation to other modes of regulating bodily conduct. ${ }^{25}$ Instead, I simply want to take up and work with Foucault's insight that diet is a mode of managing one's existence that 'enable[s] a set of rules to be affixed to conduct' and, even more, allows those rules to be 'indexed to a nature which had to be preserved and to which it was right to conform. ${ }^{26}$ In sum, Foucault helps us see diet as way of forming oneself as a responsible, ethical subject in relation to a larger social formation.

Characteristically, Foucault does not linger long on food, rushing instead to explore dietetics' relation to the bio-politics of sex and disease. For U.S. Progressive era reformers, however, alimentary dietetics lay at the heart of national stamina and the formation of responsible subjects. In this sense, early 20th-century food reformers draw our attention to a whole current of Foucaultian bio-politics that Foucault himself was slow to acknowledge. Addressing a convention of Milwaukee master bakers with her desire to see more widespread study of scientific baking, for example, home economist Elizabeth Smith, argued, 'if the proper study of mankind is man, then the study of that which makes him a capable efficient member of society and not a wretched dyspeptic, or a shell of walking contagion, is worthy of a place in any curriculum. ${ }^{27}$ Yet, Smith need hardly have spoken. Perhaps no other time in history saw as great a proliferation of research, education, theorizing, and speculation aimed at scientifically determining the proper relation among bodies, food, and the nation.

Throughout the early 20th century, scores of pure foods crusaders, nutritionists, New Nutritionists', food faddists, and advice columnists weighed in on the health of the U.S. population, and their outlook was dismal. ${ }^{28}$ 'In twenty-million homes in the United States to-day, 
McCann wrote, 'there is a complacent toleration for food abuses that sap the stamina of the race. ${ }^{29}$ While many food researchers questioned McCann's prescriptions for this problem, none challenged his diagnosis, and dozens of groups launched campaigns to improve 'national virility' or 'the stamina of the race'. 30

By the turn of the 20th century, the hypothesis that invisible microscopic organisms caused many illnesses had gained widespread scientific acceptance, and the new bio-politics of diet articulated closely with this novel understanding of disease. In the 1900s, diverse groups ranging from the Boy Scouts to the International Ladies Garment Workers Union worked to preach this 'gospel of germs' to the masses. ${ }^{31}$ School curricula impressed the 'laws of scientific hygiene' on young minds and public signage warned of the dangers of kissing and spitting. Public health had been entirely reconceived. It was no longer the solitary concern of the state, but rather the duty of all. Public health was not an activity focused on restricting abuses, but rather a positive science aimed at shaping souls, creating new habits, and producing hygienic citizens. As The American Magazine explained, praising the work of a progressive official in 1914, an old style public health official may,

Look upon his duties as chiefly repressive: he entertains the old idea that people may be punished into good behavior. He is forever shutting things up, ordering people out, arresting and prosecuting! But Doctor Evans brought to his work a new idea ... [H] saw that the only sound basis for public health was a wide understanding by the people themselves of the common rules of health. He had the soundly democratic idea that it is better to convince and educate people than it is to fine them). ${ }^{32}$

It is not hard to comprehend the material roots of the fervor - verging on obsession - with which the USA approached the new sciences of hygiene and sanitation. In 1899, diphtheria, scarlet fever, typhoid, and other communicable diseases killed in large numbers across class and race lines. Tuberculosis alone accounted for a quarter of all deaths of $20-40$-year-olds. ${ }^{33}$ By the 1920s (thanks to food safety reforms, new technologies, and rising incomes) cancer, heart and kidney diseases, and other ailments of affluence had replaced communicable diseases as the country's leading killers, but the specter of catastrophic threat remained ever present.

At the same time, the material effects of America's fixation on hygiene far surpassed its immediate impact on the way the country suffered and died. Hygiene concerns shaped fashion, raising women's hemlines and shaving away men's beards. It profoundly transformed architecture and interior design with the sleek, cleanable forms of art deco replacing the drape-heavy nooks and crannies of Victorian design. ${ }^{34}$ Although the spare visual hygiene of modernism is frequently associated with the allure of industrial machinery, it was also a biopolitical statement. LeCorbusier's 1923 'manual of dwelling' urged home designers to adopt clean visual lines that both showcased the homeowner's commitment to hygiene and, in turn, facilitated the maintenance of hygienic conditions. ${ }^{35}$

These changes permeated the pores of society, but women saw the most significant impact on their lives. Women's lives, habits, and desires represented the most important battlefield in what was increasingly understood as a desperate, no-holds barred war against disease. Women were simultaneously the greatest enemy in this war and its secret weapon. As Minnesota public health official Hibbert Winslow Hill wrote in his book, The New Public Health, 'Infectious diseases in general radiate from and are kept going by women. ${ }^{36}$ Legions of experts led the fight to rationalize and professionalize women's work in the home with the goal of defusing 
deadly ignorance and enlisting housewives in the battle against contagion. Championing the newly minted fields of home economics, 'scientific motherhood', and 'household bacteriology', these experts reconceived housework as a science of control. ${ }^{37}$ In the words of home economics pioneer Ellen Richards, women's work in the home should properly be conceived as 'the science of a controllable environment. ${ }^{38}$ As Augusta Moll Weiss wrote in her 1906 treatise on household management, 'The desire for material order must end up becoming a sort of reflex action, and even more the desire for cleanliness must end up becoming a real need. Disorder and lack of cleanliness should cause a sort of suffering in the mistress of the house. ${ }^{39}$ It was not enough to simply mount a guard against contagion; the soul must come to be defined by this vigilance. 'The slightest deviation from perfect cleanliness was a cause for social anxiety, since the invisible passage of germs could put the health of the family, companions, and even the entire nation at risk. ${ }^{40}$

Since homes could not be hermetically sealed, and since total public health was beyond the capacity of the state, women were also entreated to extend their surveying gaze into the street. ${ }^{41}$ Famously, for middle class social reformers this meant careful monitoring of the poor and their habits. In Ladies Home Journal, for example, Dr Dwight Chapin urged middle class women interested in preventing calamitous social problems to channel their 'surplus of unused mother love' toward the poor by helping to provide 'continuous oversight as to the diet and hygiene' of immigrant children. ${ }^{42}$ Critically, however, the new norm of hygiene also meant casting a web of female eyes on the external world of commerce - particularly the world of food production and distribution since few other arenas of life could be so clearly linked to the wellbeing of the household and the nation.

Thus, while self-styled 'professional sanitarians' like Caroline Bartlett Crane toured the country cleaning up butcher shops, public markets, and bakeries, ordinary women took upon themselves the task of everyday scrutiny. Women's vigilance and activism in the area of food sanitation achieved dramatic successes in food safety legislation that are well beyond the scope of this article, but in this conception women were to be both shapers of the conduct of others (i.e. through activism) and internally focused on regulating their own conduct (i.e. through the discipline of scientific housekeeping).

Women would have to be shaped and molded, and, since expert discourses almost always justified themselves by summoning specters of looming danger, the task was urgent. ${ }^{43}$ Following expert advice became not just a matter of good practice, but a requirement of competent citizenship. ${ }^{44}$ As Dr Woods Hutchinson menaced, in society's all out war with contagion, 'high standards of housekeeping' were 'well worth it at all costs' ${ }^{45}$

In this context, meticulous attention to food purity became deeply laden with a tenor of imperative action in the face of looming danger that cross-pollinated easily with discourses of racial purity and nativist politics. It is not surprising, for example, that in July 1925's Scientific American a review of current scientific thinking on the question, 'Which Races Are Best?' and its implications for immigration policy appeared sandwiched between articles on sanitary baking and methods for the safe handling of fruit juices. In an era when white Americans were exposed as never before to immigrants and their strange new foods, urgent questions of diet were never far from racial anxieties. Indeed, as germ theories of disease gained increasing popular acceptance, it often became difficult to distinguish between descriptions of food-borne contagion and the terrifying prospects of racial contamination. In a 1922 Ladies Home Journal 
article for example, Dr Royal Copeland, public health commissioner for New York City, pointed to, 'an alarming decrease in American babies' and warned that the country's racial makeup had begun to lean dangerously toward, 'black hair, black eyes, and ... swarthy complexion'. While, for Copeland, jazz music and the automobile played a pivotal role in declining white birth rates, impure milk also threatened the survival and vigor of white babies. ${ }^{46}$ Not surprisingly, for public health officials like Copeland, food-borne diseases were often associated with eastern Europeans, Mexicans, and other 'dirty' groups. ${ }^{47}$ Thus, the dangers of racial and dietary contamination demanded authoritarian interventions. As eugenicist Michael Williams argued ominously in Good Housekeeping, it was in society's better interest that, 'the dregs and waifs of our population, the people of the underworld' who simply could not 'maintain true economy in nutrition' should be 'purified and made healthful. ${ }^{48}$

As never before, individual choices in matters of diet, hygiene, sex, child care, dress, work, and recreation were closely linked to the health of the nation. Thus, subjects falling outside established norms in anything from food consumption to bathing habits could be constituted not just as a threat to themselves, but to society as a whole. During the first decades of the 20th century (as now) this burden fell especially heavily on the shoulders of mothers making choices about how to feed their families. ${ }^{49}$ In this context, the choice of bakery bread over homemade bread can be understood as something more than just a question of preference or convenience. As the next two sections show, bakers' struggle for the hearts and minds of housewives implicitly and explicitly drew on and helped reproduce this high-stakes association between food choice and competent citizenship.

\section{Control for sale: purity, hygiene, and the professionalization of baking}

Did store-bought or home-baked bread offer a safer, easier, and more hygienic way to feed a family? Through the early 20th century, professional bakers mobilized to convince housewives that the unarguable answer to this question was that, 'Bakers' Bread is Better'. 'For every master baker there are a thousand housewives, and every housewife is either a competitor or a customer,' George Haffner, president of the National Association of Master Bakers, warned at the group's 1915 meetings. Winning over housewives, he argued, would require a full-scale mobilization, and that mobilization could not wait. ${ }^{50}$ During this period of rapid industrial innovation, the baking industry faced three potentially crippling obstacles to expansion: (1) a widespread sense that bakery bread was inferior to its homemade counterpart; (2) the historical tendency for grain food consumption to decline relative to the consumption of meat, vegetables, and fruits as incomes rose in society; ${ }^{51}$ and (3) the fact that technological innovation in baking, spurred on by competition, easily outpaced the growth of demand (leading to a classic crisis of overproduction, in the Marxist sense, and producing massive concentration and centralization in the baking industry). ${ }^{52}$

Yet, despite the dire predictions of industry experts and food economists, per capita consumption bread actually rose between the Jazz Age and the Post War from 75.5 pounds per person in 1923 to 94.1 pounds in $1947 . .^{53}$ And, as we have seen, by the 1930 s, nearly all of that bread was store bought. Bakers had not only convinced the country that, 'Bakers' Bread 
is Better,' but also that bread itself still had a place in the sleek world of modern eating. This success turned on many factors, but as I argue later, it turned in part on the ways in which sliced white bread articulated with discourses of hygiene, purity, and control.

\section{Re-positioning baking}

The articulation between hygiene and bakery bread would have appeared somewhat outrageous at the turn of the century. Bakery bread was one of the few industrially processed foods widely associated with poverty rather than affluence. ${ }^{54}$ Early industrial bakeries were more 'dark satanic mills' than 'model palaces,' and their owners were among the first groups of businesspeople in the country to face the ire of food purity campaigners. ${ }^{55}$ Household management experts at Good Housekeeping, in turn, reinforced this negative connotation, warning readers that 'the conflict of the [bakery] loaf with dirt and danger is not exaggerated. ${ }^{.56}$ Food crusaders accused bakeries of whitening bread with plaster of Paris, sulfate of lime, borax, bone, pipe clay, chalk, alum, and other nefarious compounds, while fierce debates raged from the pages of women's magazines the halls of the U.S. Supreme Court over whether bleaching flour with chlorine gas constituted a criminal act. Dr Harvey Wiley, leading food purity campaigner, urged consumers to 'Save the bread of the nation!' from 'further adulteration. ${ }^{.57}$

Meanwhile, Caroline Bartlett Crane singled out bakeries, along with meat markets, as a central focus of professional sanitation. A reporter who accompanied Crane on one of her urban atrocity tours described the interior of Montgomery, Alabama's bake shops, 'The front room of these fairly glistened with cleanliness ... but hardly had the women crossed the dividing line between the shops and work rooms than they stopped in horror. Grime, cobwebs, and dirt were everywhere'. After Crane's Alabama visit, progressive women's groups drew up a 'white list' of acceptable establishments and launched a boycott of offending bakeries that caused an immediate 25 per cent drop in sales. ${ }^{58}$

Bakery bread was not just seen as more expensive and of lower quality than home-baked, it was a potential biohazard. In an age when the existence of microorganisms was increasingly recognized, but poorly understood, even bread's living origins raised fears, as this evocative and unsavory 1905 description of bread biology suggests: 'Bread rises when infected with the yeast germ, because millions of these little worms have been born and have died, and from their dead and decaying bodies there rises a gas just as it does from the dead body of a hog or any other animal. ${ }^{59}$

Worries circulated through society about 'bread diseases' - molds and bacteria growth that infected bread with 'sticky masses' and blood-colored clots. ${ }^{60}$ Bread must be made with great care, experts warned, or consumers faced the risk of 'acidosis' and other physical menaces. In this context, could bread made by distant and unfamiliar bakers be trusted?

Speaking, in her words, 'For one million organized housewives,' Ethel Rahbar of the National Housewives League confronted bakers with this question directly at their 1916 annual meeting in Salt Lake City:

The housewife today is availing herself of the full knowledge of foods and their value in order to develop and conserve the mental and physical well-being of the individual ... If we do not put the proper food values into the stomachs of our families, what do we get out of it? A condition physically and mentally that is a menace to 
society. Intelligent bakers understand that if they want to compete successfully with the home kitchen they must use equally good materials, and it you wish to win the housewife let your trump card be cleanliness and good materials ... Enlightened housewives not only demand good bread, but they demand bread that is handled respectably; that is, in a cleanly manner. ${ }^{61}$

Bakers quickly internalized many aspects of this advice. At the Salt Lake City meeting one baker rose to offer his comments on Rahbar's talk,

I found as I appeared before the different women's clubs in Montana that they object not so much to the idea of baker's bread, but to the fact that it may not be clean ... The consumer not only demands that the bakeshop be clean, but that the baker himself be clean in person, in morals, and in his conduct in the street. I believe that the baker should see that the people in his employ are clean in their habits as far as possible, and that will go a long way to eliminate the prejudice which exists against baker's bread. If you can get a class of men to handle it that the women have confidence in, there will be no trouble in converting them to the use of baker's bread. ${ }^{62}$

The Association president responded to great applause, 'I want to compliment Mrs Rahbar on her selection of the term "respectable" applied to bread. I hope that designation will sink into the minds of all the bakers in the land, that the question of clean bread is a question of respectability. ${ }^{36}$ The NAMB had already adopted a code of Sanitary Standards at their 1912 meetings in response to a spate of newspaper reports that year on dirty bakeries, but enormous challenges in overcoming widespread perceptions of 'the conflict of the [bakery] loaf with dirt and danger' still faced the industry.

In this milieu of pure foods activism and industrial innovation, the most miraculous invention of early 20th-century baking was not sliced bread (despite the latter's immortalization as America's 'best thing'). It was wrapped bread. Bread wrapping emerged as a sanitary practice as early as 1895 , but no reliable wrapping machine existed until 1913. By then consumer demand for wrapped bread had mounted, and, according to Wiley, 'increasing interest in hygienic bread wrapping' made this a central arena of pure food struggle. ${ }^{64}$

Bakers, for their part, fiercely resisted consumer pressures. Citing the increased cost of wrapping, quicker staling, effects on bread flavor, and problems with mold, bakers fought tooth and nail against calls for wrapping levied by 'zealous inspectors', 'pure foods magazines', and consumers lured by the novelty of 'sealed package food preparations ... without any reference to or consideration of what it is that is to be wrapped and handled in this way. ${ }^{65}$ Debates over wrapping consumed the 1912 and 1913 NAMB meetings to such an extent that, in 1913, the Association commissioned a firm of consulting and analytical chemists to make a definitive report on the scientific effects of bread wrapping. After a year of intensive studies on mold formation, 'water fixation', chemical compositions, bread bacteriology, and different wrapping materials, the firm concluded that bread should be wrapped as a matter of sanitation - but not indiscriminately. The chemists endorsed permeable materials over waxed paper and warned against wrapping certain breads. ${ }^{66}$ These expert findings did little to assuage most bakers' fears however, and in 1915, when Houston area food safety crusaders placed a bread wrapping referendum on the ballot, local bakers mobilized to defeat the issue with strong national support.

Nevertheless, consumer pressures and food safety advocacy eventually wore away bakers' resistance, and by the 1920s commercial bread was almost universally wrapped. Indeed, when, after much resistance, bakers gave in to the notion of food purity, they did so with abandon, making sanitation their number one selling point. Sidelining taste, aroma, freshness, and even 


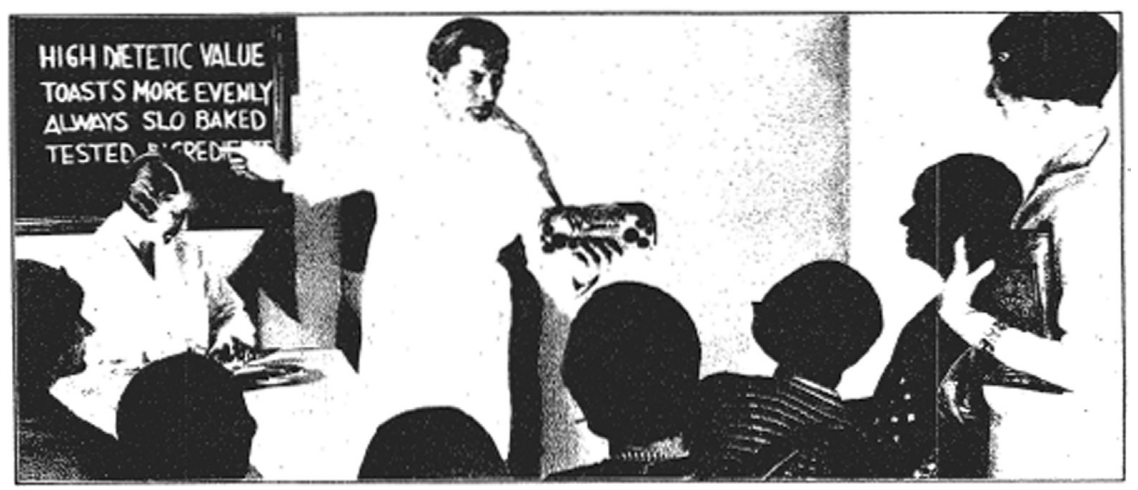

FIGURE 1 A lab-coated scientist explains the benefits of Wonder Bread to a gathering of well-dressed women in this ad from 1929. The title reads: 'Mothers here adopt new bread. Widely urged for school children.' New York Times 14 April 1929, p. 104.

price, bread advertising touted purity and hygiene. Scientific baking promised to deliver perfectly hygienic bread - untouched by human hands from dough to dinner table. In doing this, the baking industry turned the binary of purity and contagion on its head: thanks to the techno-scientific control they exercised over bread, industrial bakers argued, it was homemade (read: dirty and dangerously inconsistent) bread that posed a safety threat. In order to credibly make this claim, baking had to be entirely repositioned in the minds of consumers, and this repositioning can only be understood by examining the professionalization of baking.

\section{Experts agree - mother's bread is deadly}

The professionalization of baking was bio-political from the start. The first formal academy of bread baking was founded in 1780s France by Antoine Auguste Parmentier, an army apothecary. 'If there are schools for veterinaries who study the feeding of animals,' he wrote, 'why should there not be a school for bakers, to whom the health of the nation is entrusted. ${ }^{.67}$ Unfortunately for Parmentier - who also introduced fruit sugar and widespread cultivation of the potato to France - his efforts to ensure national security through the rationalization of baking were too little, too late: the school collapsed a just few years after opening when hungry mobs stormed the Bastille. By the late 19th century, however, baking institutes had spread across Europe and the USA, and were slowly eroding baking's traditional apprenticeship model of education. In the expert-infatuated USA, the Wahl-Henius Institute of Fermentology, the Wahl Efficiency Institute, the Chidlow Institute, and the Siebel Institute of Technology championed the scientific study of bread chemistry, biology, and technology. The National Association of Master Bakers - despite its name's association not an age of master artisan production - offered its members an endless stream of scientific educational opportunities. Plenary sessions at its annual meetings, for example, informed bakers of the latest scientific thinking on wheat chemistry, rational cost accounting, the effects of salts on fermentation, accurate weighing and measuring, efficient movement, the physiology of taste, bacteriology, and bakeshop etomology, among other topics. 
Bakery research targeted the unruly, living nature of bread, seeking to enable control over every aspect of the baking process. The industry introduced new controls over weights, measurements, and quality of ingredients. Electricity allowed unprecedented control over temperature at every stage of what was quickly becoming an assembly line. Dough was mixed in refrigerated conditions to prevent overheating, transferred to temperature-controlled proofing and fermentation chambers, and then baked using the most accurate ovens in human history. By 1930, only fermentation defied absolute control, with the living nature of yeast setting strict limits on the quantity of dough that could rise at one time. Over the next few years, the industry mobilized to face this last challenge, investigating chemical dough conditioners and production processes that would soon break through the yeast ceiling. In the end, as William Panschar wrote, 'as engineers rather than craftsmen, bakers were able to produce consistently a high quality, uniform loaf of bread. The degree of control exacted over formulas, ingredients and production processes were now far beyond the skills of the housewife to match. ${ }^{68}$

Not surprisingly, this legion of scientific baking was almost exclusively male. Indeed, in 1924, there were twice as many more women working as physicians, dentists, and surgeons in the USA than women professional bakers. In fact, professional baking was one of the least feminized occupations in the nation, with only law enforcement, chemistry, clergy, and the legal profession reporting fewer women in their ranks. ${ }^{69}$ Thus, a cadre of male professional bakers, armed with the magic of science, squared off against a country of home-baking housewives. Bakers argued that,

The average housewife of today who bakes bread is living in the dark; she is ignorant of what the up-to-date method of baking consists; She has to be educated, the same as a child is educated to eat from a plate - the only difference being that our task is far harder than teaching a child, whose mind is receptive to instruction and learning. ${ }^{70}$

Scientific American critiqued housewives' use of, 'uncertain ferments which cause sour and otherwise undesirable fermentation,' and Ellen Richards compared home baked loaves with 'laboratory bread' and found the former lacking. ${ }^{71}$ For Richards, tradition and lack of control meant that home-baked bread was not just inferior, but also potentially dangerous. 'The custom of some housewives of wrapping the hot loaf in thick cloth that the steam may soften the crust is entirely wrong from a bacteriological standpoint,' she argued, and extra care was needed for coarse breads which contained particularly resistant bacteria. ${ }^{72}$ She urged housewives to follow strict sanitary procedures, and educate themselves by conducting yeast gas experiments in test tubes and Petri dishes. To drive home the weight of her warning she stressed that 'Every case of typhoid fever is due to somebody's criminal carelessness. ${ }^{73}$ Faced with these risks, why experiment or chance the criminal carelessness of untamed bread when the scientific bakery was near? Moreover, as the next section contends, this aura of scientific control surrounding industrial baking was reinforced by the visual spectacle of the loaf itself.

\section{The spectacle of clean}

In an age obsessed with the streamlined aesthetics of scientific progress and the visual spectacle of purity, hygiene, and progress, the new loaves were also clearly engineered to appear as small objects of arte moderne: sleek, sparkling clean, whiter than white, and uniformly sliced. 
As John Varty argues, it should come as no surprise that industrial white bread looks like Bauhaus furniture. ${ }^{74}$ We can speak of a clear and weighty traffic between modern design and the cultural politics of purity, health, and progress during the period when industrial bread emerged. As Christine Cogdell suggests, by the 1930s, the design of everyday objects reflected and advanced the ideology of social eugenics, with the visual ideals of streamlined objects, dirt-free environments, and racial hygiene continually overlapping and reinforcing each other. ${ }^{75}$ Numerous features of the sleek new industrial loaf could be examined in this light, but this section focuses on connections between bread's whiteness and larger discourses of purity and progress.

During the second half of the 19th century, flour millers in Europe and then the USA replaced ancient millstones with porcelain, and later steel, rollers. These new roller mills proved particularly adept at turning unwieldy hard wheats into fine white bread flours. ${ }^{76}$ By the 1880s, the new mill technology ground out thousands of barrels of low-cost white bread flour and a steady stream of controversy. Then, as now, antagonism toward white flour came heavily dusted with populist fears of industrialization and its unnatural colonization of life. Then, as now, critics resoundingly attacked white flour as industrial abomination and threat to the health of the population. But this was a two-sided debate, and in the early 20th century both white and dark flour supporters articulated their positions in bio-political terms. As the debate grew in intensity, eventually reaching the U.S. Supreme Court, critics and supporters alike framed the debate in terms of national health: Was white flour a food deprived of its vital essence and a drain on national stamina, or a modern miracle of grain finally freed from dangerous dirt and contamination? By the 1930s, although still subject to constant challenge from whole wheat backers, white bread would emerge as the clear victor in this struggle. Even as they grounded their claims in scientific research, white bread critics were forced to pose their concerns in anti-modern terms, often romanticizing the dark bread of 'savage' Others. ${ }^{77}$ White bread had become a clear visual icon of modern progress. This association of white bread with progress operated in multiple arenas, including the dynamics of scientific expertise discussed earlier. Here, I focus on one small arena: the contingent connection between industrial white bread and an emerging symbolics of whiteness, where the color white was closely associated with norms of cleanliness and purity.

Early 20th-century attacks on white flour built on the late 19th-century religious-inflected 'food faddism' of William H. Kellogg and William Graham. ${ }^{78}$ White flour, as Alfred McCann suggested, was a product of greedy industrialists that violated, 'the provisions of the Creator' and produced delinquency. America must defy these 'Moneybags', he argued, and return its eating practices to the basic laws of God. ${ }^{79}$ In a cascade of popular publications experts like Henry Sherman, Elmer McCollum, and Harvey Wiley joined the fray, attacking America's 'rage for whiteness'. ${ }^{80}$ They pointed to the threat of malnutrition and 'white bread acidosis', a lethal condition brought on by eating too much white bread. Only 'undenatured or unrobbed wheat ... is a true nerve, blood and bone food ... rich in the life-giving principles. ${ }^{91}$

In the heat of these debates, one key innovation asserted itself as the central target of ire for the pure foods movement: chemical bleaching. All flour whitens as it ages, but until the 20th-century desire for whiteness had to be weighed against the deteriorating quality of older flour. In 1904, however, millers overcame this natural obstacle with the invention of the Alsop Process of chemical bleaching. As Scientific American argued, 'The uncontrollable and time-consuming aging and maturing of flour by nature ... has been superseded by a safe, 


\section{The Story of an American Busliness Success}
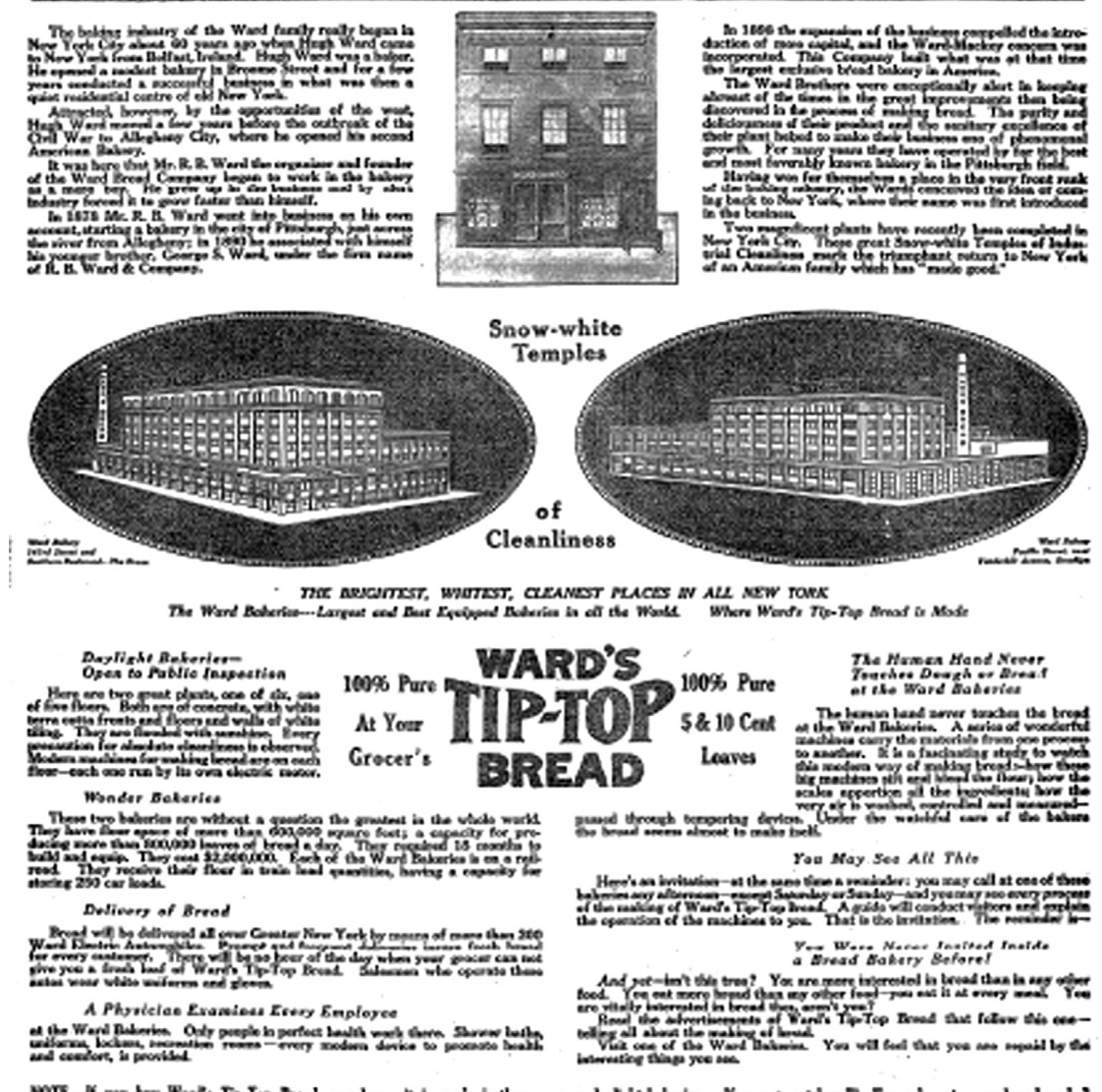

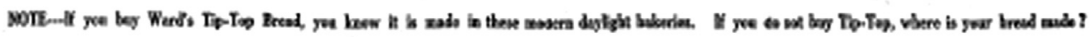

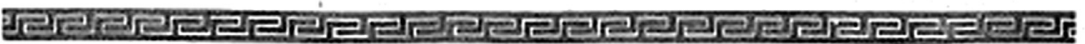

FIGURE 2 'Snow-white temples of cleanliness', Ward Bakeries advertisement, 1911.

rapid, and far more effective process based on scientific principles. ${ }^{82}$ By 1930, when Scientific American introduced readers to the latest whitening agent ('Do-White ... a finely-ground powder with a pleasing leguminous taste') chlorine gas, nitrogen trichloride, and nitrogen peroxide were already widely used as flour bleaching agents.

Chemical bleaching was immediately accepted as standard practice in the milling industry, but pure foods advocates like Harvey Wiley and Alfred McCann formed ranks against artificial whitening, charging millers with adulteration. In 1914, when the U.S. Supreme Court ruled in favor of millers, Wiley raged against the decision warning that flour would forever more be, 'as white and waxy as the face of a corpse. ${ }^{93}$ Anti-white flour efforts achieved 
some success, ${ }^{84}$ but Wiley's sepulchral vision of whiteness vied with an increasingly dominant and luminous sense of the color.

At least since the early medieval period whiteness has had a Janus-faced social and religious symbolism in the west; the color could equally stand for life or death, purity or pallor. In the early 20th century, however, the meaning of white was increasingly stabilized around notions of purity and hygiene. At a time when white America's collective sense of the ambiguous shades of racial whiteness was more unstable and fractious than at any other time in its history, the simple color white provided a safe and reassuring haven. ${ }^{85}$ Whiteness, as never before, had become synonymous with purity, and this association manifested itself in multiple arenas, including food production. ${ }^{86}$ Whether in clothing, kitchens, appliances, or water closets, everything was white. Dark Victorian home interiors gave way to smooth white surfaces and schools, women's magazines, advertisers, and home economists implored women to keep their laundry, aprons, and towels bleached to the whitest of white. ${ }^{87}$ The color white had been normalized as a field of clean, something that would help it stand its ground against the health food arguments of dark bread proponents.

In the anxious, early decades of germ theory home economists had to convince housewives that such improbable particles really existed. Ellen Richards, for example, encouraged women to see for themselves by capturing airborne bacteria in Petri dish 'dust gardens'. If done properly this experiment in 'household bacteriology' would soon reveal, 'minute lightcolored specks ... on the surface of the jelly. These will be seen to grow larger, to become of different colors - pink, yellow, orange, green, blue, possibly a deep red' ${ }^{88}$ Women were encouraged to 'write down an accurate and full account as to the time, appearance, conditions of temperature, light, etc.' and then experiment with different conditions using a microscope to observe the results if possible. Once armed with this basic scientific understanding of the invisible world, women could turn their gaze on even deadlier foes: bread molds, spoiled milk, and stealthy colonies teaming on the surface of meat.

While home economists encouraged the average housewife to visualize germs through scientific experiments, there were easier ways to help women identity danger in their midst. Dust, in particular, offered a straightforward way to communicate the presence of tiny threats. Thus, during the early 20th century, dust had become intrinsically connected to disease; a fear fanned by T. Mitchell Prudden's Dust and its Dangers, which spread the idea of 'dust-poisoning' through U.S. society. The color white in turn - normalized as a pure and uncontaminated visual field - allowed society to constantly police surfaces for dust and dirt. ${ }^{89}$ Despite the fact - admitted by Richards, Prudden, and others - that not all dust carried germs and not all dirt was dark, pure fields of white were increasingly touted as a way to visualize the invisible world of contagion. Woods Hutchinson, for example, wrote in general praise of the color white in an ironic American Magazine article: The prevalence of 'smoke and grime' in urban America he wrote, has 'been of definite and direct benefit' to the country because its overpowering visibility forced even swarthy immigrants to adopt higher standards of cleanliness, making them 'scrub not just once a day, but thrice'. The color white - particularly from white wash and white paint - was central to this visibility he argued, because, Anything in the way of dirt or garbage which showed up against this shiny background was so conspicuous that shame alone compelled the Polacks and Hungarians in the district to get rid of it in some way. ${ }^{90}$ If, as early 20 th-century experts loved to repeat, 'dirt was matter out of 
place,' white had been normalized as the defining measure of whether something was in or out of place. The color white had become a disciplinary technology closely associated with medical science and sanitation.

This proved true with bread as well. Even Alfred McCann - one of the country's fiercest anti-white bread crusaders - understood the visual discipline of the white loaf. He wholeheartedly supported dark bread, but attacked adulterers who took advantage of the 'dusky color' of their loaves to conceal impurities. If this did not happen, he argued, 'The white bread maker would not then point to his immaculate loaf, free from the faintest tint of color. He would not contrast the "chastity" of that white loaf with the "defilement" of the dark one." Charles Briggs writing in Science, summed up the connection consumers had made between white bread and sanitation: 'To all appearances ... the general public is continuing in its belief (justified both by the bacteriological count and the microscopic examination) that whiteness or creamy whiteness is a sign of cleanness. ${ }^{.92}$ In a time when bread production was increasingly taking place outside the home and out of consumers' sight, the whiteness of loaves increasingly substituted for the direct ability to monitor the baking process and reassured consumers of bread's compatibility with modern conceptions of purity, health, and progress.

\section{Conclusions}

In a 1916 article entitled, 'Modern bread-baking: the loaf untouched by human hands in the process of making,' Scientific American predicted that bakery bread would grow in popularity thanks to, 'the baker's better knowledge of fermentation, better knowledge of all the ingredients entering the loaf, more sanitary methods of production, and because of the absolute cleanliness in the handling of the baked loaf. ${ }^{93}$

The magazine's predictions proved correct. Conceived as a techno-science of cleanliness and control, modern baking found a place for its bread in modern diets. This path to modern bread did not follow a straight line of technological advance, but rather took detours and short-cuts through the emotionally and politically charged world of purity and hygiene. In tracing the entanglements of bread, Progressive era activism, and deep social anxieties, the article expands our understanding of a critical juncture in the making of the American diet, while placing historical studies of food safety into conversation with Foucaultian bio-politics.

While food commodification and industrialization are often glossed as forces of cultural disenchantment and destruction, this article has shown that 'the making of modern bread' turned on a more productive form of power - one that shaped new subjects and gave rise to new emotional attachments to food. Critically, in the case of bread, this productive power operated by connecting consumer choices to larger constructions of purity, hygiene, and responsible citizenship. Thanks to widely circulating discourses of scientific control and the visual spectacle of cleanly whiteness, bread consumption choices became a way in which people positioned themselves and were positioned within social hierarchies.

Of course food choices are always about positioning oneself and being positioned within social hierarchies - there is nothing new about this claim. ${ }^{94}$ What is interesting about studying the case of early 20th-century bread consumption in the USA is the way it illuminates the specific implications of having this process of positioning-being positioned play out in 
relation to a particular bio-political formation of social hierarchy. In other words, this is not just about distinction or social stratification in general, but rather a specific form of social difference constructed around the very lines of life and death. Focusing on difference in this way, in turn, illuminates a number of more general insights into what happens when social constructions of food safety get cast in bio-political terms - a process that is still very much a part of early 21 st-century food politics. One of these implications, drawn from the early 20 th century and applicable to the early 21 st century, merits the final word in this article.

Food safety struggles articulated as bio-political struggles nearly always hinge on organic notions of natural and social purity that pose a homogenous organic society against external threats. ${ }^{95}$ As we saw, early 20th-century discussions of bread consistently placed how one eats in relation to threats against individual bodies and the larger social body. Defining good eating in relation to impending threat meant that one's response must be swift and decisive. There is not much room for creative engagement here: you do not try to 'work with' or 'transform' a threat like this; you build up the barricades and batten down the hatches.

There is nothing particularly wrong with this on a certain level: Who mourns the isolation and elimination of typhus? But, what becomes clear from the story of bread is that understandings of threat to the social body do not remain neatly moored in 'benevolent' binaries. They overflow and reinforce other kinds of exclusion, indexing them to 'a nature that had to be preserved' and giving them the urgent aura of life and death. ${ }^{96}$ Indeed, as we saw, early 20thcentury discourses of food and racial purity reinforced one another to such an extent that even the most radical reforms achieved by pure foods campaigners were tainted with subtle (and not so subtle) racism. Food and diet clearly served as central means through which exclusionary categories of race and nation were understood and produced in early 20th-century America.

Tracing this dark side of food purity takes us to the heart of Foucault's critique of biopolitics. Bio-politics is the positive power to establish the health and security of a population by creating new, responsible subjects ('at all costs', as Woods Hutchinson might have urged). Yet bio-politics' protective measures require a carefully defended architecture of boundaries, divisions, and hierarchies among and within populations aimed at defining and eliminating 'the biological threat to $\ldots$ the species or race. ${ }^{, 97}$ Thus, as Foucault contends, social improvement couched in a language of bio-politics must, 'introduce a break into the domain of life that is under power's control: the break between what must live and what must die.'

In most cases this politics of life and death takes benevolent forms; indeed, food purity discourses may achieve wide-ranging improvements in the health and security of a defined population (typically wealthy, white consumers), but they are not innocent. They structure the world of life into comparable ranks and actionable hierarchies, safeguarding privileged spheres of life while targeting outliers as enemies. Critically, as both the story of white bread and the contemporary examples briefly presented earlier suggest, purity and hygiene are privileged and politically powerful notions in a bio-political society, but this efficacy comes with a cost.

\section{Acknowledgements}

The author acknowledges valuable critical input from Mona Domosh, Melanie DuPuis, Julie Guthman, Susanne Freidberg, two anonymous reviewers for Cultural Geographies, and members of the University of California, Irvine Humanities Research Institute's 'Eating Cultures: Race and Food' program. Much earlier 
versions of this article were presented at a session of the 2005 meeting of the Association of American Geographers and a 2005 workshop on 'White Food: Race and the Politics of Purity' at the University of California, Santa Cruz

\section{Biographical Note}

Aaron Bobrow-Strain is Assistant Professor of Politics at Whitman College. He is the author of Intimate Enemies: Landowners, Power, and Violence in Chiapas (Duke University Press 2007) and is currently writing a cultural history of sliced, white supermarket bread. He can be contacted at: Whitman College, 345 Boyer Avenue, Walla Walla, WA 99362, USA; email: straina@whitman.edu

\section{Notes}

1 C. Beecher and H. Beecher Stowe, The American woman's home (New Brunswick, Rutgers University Press, 2002), p. 131.

2 Ibid. p. 134.

3 M. Warren, 'The science of oven management', Ladies home journal (May 1923), p. 150.

4 N. Bengston and D. Griffith, The wheat industry: for use in schools (New York, Macmillan, 1924), p. 184. This is but one of many examples of the new scientific language used to talk about bread baking that began appearing in textbooks, cook books, and women's magazines in the 1920s.

5 L. Wolfe, 'The growth of bread production', Baking industry (12 April 1952), p. 122; Western baker (January 1937), p. 21.

6 W. Panschar, Baking in America: economic development, volume 1 (Evanston, Northwestern University Press, 1956).

7 National Association of Master Bakers, Proceedings of the eighteenth convention (Chicago, National Association of Master Bakers, 1915), p. 12.

8 Panschar, Baking in America; Baking industry, Special anniversary issue (12 April 1952).

9 For example, A. Sayer. '(De)commodification, consumer culture, and moral economy', Environment and planning D 21 (2003), pp. 341-57; K. Polanyi, The great transformation: the political and economic origins of our time (Boston, Beacon Press, 1957).

10 For discussions of purity, health, and hygiene in relation to other foods industrialized during this period see D. Block, 'Saving milk through masculinity: public health officers and pure milk, 1880-1930', Food and foodways 13 (2005), pp. 115-34; M. Domosh, 'Pickles and purity', Social and cultural geography 4 (2003); M. DuPuis, Nature's perfect food: bow milk. became America's drink. (New York, New York University Press, 2002).

11 C. Cogdell, Eugenic design: streamlining America in the 1930s (Philadelphia, University of Pennsylvania Press, 2004); M. Ngai, Impossible subjects: illegal aliens and the making of modern America (Princeton, Princeton University Press, 2004); D. King, Making Americans: immigration, race, and the origins of the diverse democracy (Cambridge, Harvard University Press, 2000); M. Jacobson, Whiteness of a different color: European immigrants and the alchemy of race (Cambridge, Harvard University Press, 1998); C. Calhoun, The gilded age: essays on the origins of modern America (Wilmington, Scholarly Resources, 1996); N. Painter, Standing at Armageddon: the United States, 1877-1919 (New York, WW Norton, 1987).

12 On this trend see H. Levenstein, Revolution at the table: the transformation of the American diet (Berkeley, University of California Press, 2003).

13 Although Americans consumed more bread than any other single food well into the 20th century, the massive commodification and industrialization of bread has received almost no attention in 
scholarly work on the history and cultural politics of food; e.g. H. Levenstein, Revolution at the table; Paradox of plenty: a social history of eating in modern America (Berkeley, University of California Press, 2003); C. Counihan, Food in the USA (New York, Routledge, 2002); R. Pillsbury, No foreign food: the American diet in time and place (Boulder, Westview Press, 1998); L. Shapiro, Perfection salad: women and cooking at the turn of the century (New York: Farrar Straus and Giroux). Bread, it seems, appears too innocuous and quotidian to merit much attention, even among scholars concerned with the everyday politics of eating. John Varty's excellent research on Canadian wheat and flour improvement represents the only other effort to critically address the history and politics of bread science in North America. See: J. Varty, 'On wonder - why mass-produced bread looks a little like Bauhaus furniture', paper presented a at the annual meeting of the Society for the History of Technology, (3-6 November 2004); 'First the loaf: a hybrid history of wheat improvement', paper presented at the Yale University Agrarian Studies Colloquium (24 September 2004); 'On protein, prairie wheat, and good bread: rationalizing technologies and the Canadian state, 1912-1935', Canadian historical review 85 (2004), pp. 721-53. Steven Laurence Kaplan's work, which chronicles of struggles over bread in post-War France, tells a different and much later story from the U.S. case discussed here. See L. Kaplan, Good bread is back: a contemporary bistory of French bread (Durham, Duke University Press, 2006).

14 For example, B. Donald and A. Blay-Palmer, 'The urban creative-food economy: producing food for the urban elite or social inclusion opportunity?', Environment and planning A 38 (2006), pp. 1901-20; J. Guthman and M. DuPuis, 'Embodying neoliberalism: economy, culture, and the politics of fat', Environment and planning D 24 (2006), pp. 427-48; R. Slocum, 'Anti-racist practice in the work of community food organizations', Antipode 38 (2006), pp. 327-49; M. DuPuis and M. Goodman, 'Should we go home to eat?: toward a reflexive politics of localism', Journal of rural studies 21 (2005), pp. 359-57; S. Freidberg, French beans and food scares: culture and commerce in an anxious age (Oxford, Oxford University Press, 2004); J. Guthman, Agrarian dreams: the paradox of organic farming in California (Berkeley, University of California Press, 2004).

15 H. Markel and A. Stern, 'The foreignness of germs: the persistent association of immigrants and disease in American society', The Milbank quarterly 80 (2002), pp. 757-88; W. Troesken, 'The limits of Jim Crow: race and the provision of water and sewerage services in American cities', Journal of economic bistory 62 (2002), pp. 734-72; N. Shah, Contagious divides: epidemics and race in San Francisco's Chinatown (Berkeley, University of California Press, 2001); N. Tomes 'The making of a germ panic, then and now', Public health 90 (2000), pp. 191-9; N. Tomes, The gospel of germs (Cambridge, Harvard University Press, 1998); N. Tomes, 'Spreading the germ theory: sanitary science and home economics, 1880-1930', in S. Stage and V. Vincenti, eds, Rethinking home economics (Ithaca, Cornell University Press, 1997); A. Stern, 'Buildings, boundaries, and blood: medicalization and nation building on the U.S.-Mexico border, 1910-1930', Hispanic American bistorical review 79 (1999), pp. 41-81.

16 A. Bobrow-Strain, 'Kills a body twelve ways: bread fear and the politics of "what to eat?", Gastronomica 7 (August 2007).

17 M. Foucault, Society must be defended (New York, Picador, 2003); 'The politics of health in the eighteenth century', in P. Rabinow and N. Rose, eds, The essential Foucault (London, The New Press, 2003); The history of sexuality, volume 1: an introduction (New York, Vintage, 1990); The history of sexuality, volume 2: the use of pleasure (New York, Vintage, 1990). See also D. Moore, J. Kosek, and A. Pandian, eds, Race, nature, and the politics of difference (Durham, Duke University Press, 2003); N. Rose, Powers of freedom: reframing political thought (Cambridge, Cambridge University Press, 1999).

18 Foucault, Society must be defended, p. 254.

19 Attentive readers will spy several other important theoretical threads that bob up and down in the narrative: a Latourian fascination with the ways 'scientific baking' wrestled with the unruly, living nature of yeast bread; questions about the relationship between technology, capitalist development, and 
cultural politics in the realm of baking (an ensemble I call 'carbohydrate capitalism'); and a puzzle about the effective relation between the discourses of public health experts and housewives' actual consumption practices. Alas, each of these intriguing threads receives only a hint of cursory attention here.

20 L. Goodwin, The pure food, drink, and drug crusaders, 1879-1914 (London, Macfarland, 1999); J. Young, Pure food: securing the Federal Food and Drugs Act of 1906 (Princeton, Princeton University Press, 1999).

21 Foucault, 'The politics of health', p. 341.

22 Foucault, Society must be defended, p. 244; A. McCann, The science of eating (New York, George H. Doran, 1918).

23 Foucault, Society must be defended, p. 246.

24 Foucault, 'The politics of health', pp. 341-5.

25 It is worth noting, for example, that Foucault frames Greek dietetics (based on positive incitements to shape oneself as an ethical subject) in a generally positive way compared with Christian sexual morality based on negative prohibitions.

26 Foucault, The use of pleasure, p. 101.

27 Milwaukee Bakers' Institute, Proceedings of the Milwankee Bakers' Institute, second season (Madison, University of Wisconsin Press, 1910), p. 102.

28 See M. DuPuis, 'Angels and vegetables: a brief history of food advice in America', Gastronomica 7 (2007).

29 McCann, The science of eating, p. 15.

30 Good housekeeping magazine, for example, emerged as an important voice in the bio-political battle for the health of the nation. Inaugurating its landmark 'Honor Roll of Pure Foods' in 1905, Good bousekeeping magazine boldly declared that, National virility ... depends upon individual health to such an extent, and this in turn is so largely governed by our food, that the healthfulness of foods is a matter of the most serious consequences to the nation' (p. 361).

31 Tomes, The gospel of germs; S. Hoy, Chasing dirt: the American pursuit of cleanliness (Oxford, Oxford University Press, 1995).

32 'The new Chicago and its progressive people', American magazine (March 1914), pp. 52-4.

33 Tomes, 'Spreading', p. 26.

34 Tomes, The gospel of germs; T. Smith, Making modern America: industry, art, and design in America (Chicago, University of Chicago Press, 1994); A. Forty, Objects of desire (New York, Pantheon, 1986).

35 Forty, Objects of desire, p. 157.

36 Quoted in Tomes, 'Spreading', p. 49.

37 See E. Murphy, 'Expertise and forms of knowledge in the government of families', The sociological review 41 (2003); J. Rutherford, Selling Mrs. Consumer: Christine Frederick and the rise of household efficiency (Athens, University of Georgia Press, 2003); R. Apple, 'Constructing mothers: scientific motherhood in the nineteenth and twentieth centuries' Social history of medicine 8 (1995), pp. 161-78. 
47 Markel and Stern, 'Foreignness'; Shah, 'Contagious divides'; King, 'Making Americans'; Tomes, 'Germ panic'.

48 M. Williams. 'Fletcherizing with Fletcher', Good housekeeping magazine (May 1907), p. 505.

49 Murphy, 'Expertise'.

50 National Association of Master Bakers, 1915 proceedings.

51 Often called the rule of the limited stomach, Engle's Law is foundational to food economics. The theorem, along with several corollaries, states that because food commodities - particularly staple grains - have very low price and income elasticities demand for those items does not increase substantially in response to rising consumer incomes or falling food prices. As incomes rise then, food purchases decline as a percentage of total spending, placing unique competitive pressures on capitalist food producers.

52 A full discussion of these economic dynamics - the particular challenges and constraints of what I call 'carbohydrate capitalism' - is not possible here. It is the subject of a larger book project.

53 Wolfe, Bread production, p. 122.

54 S. Strasser, Never done: a bistory of American housework (New York, Pantheon, 1982), p. 23.

55 Goodwin, Pure food; Tomes, The gospel of germs.

56 H. Barnard, 'The one objection to baker's bread', Good bousekeeping magazine (May 1913), p. 694.

57 H. Wiley, 'Fooling with flour: the nation's bread is in danger', Good housekeeping magazine (March 1914), p. 119.

58 H. Bennet, 'Cleaning up the American city', American magazine (September 1913), p. 48.

59 'Uncooked foods', Good housekeeping magazine (July 1905), p. 98.

60 'Bread diseases', Scientific American (October 1923), p. 225.

61 North American Master Bakers, 1915 proceedings, p. 142.

62 Ibid., p. 143.

63 Ibid., p. 143.

64 Wiley, 'Returns'.

65 National Association of Master Bakers, Proceedings of the seventeenth convention (Chicago, National Association of Master Bakers, 1914), p. 163.

66 National Association of Master Bakers, 1914 proceedings.

67 Quoted in L. Rumsey, 'Progress of education in baking', Baking industry (12 April, 1952), p. 126.

68 Panschar, Baking in America, p. 123.

69 Women's News Service, Women of today (Philadelphia, John C. Winston Company, 1924).

70 National Association of Master Bakers, Proceedings of the eighteenth convention, p. 88.

71 'Modern bread-making', Scientific American, p. 88; E. Richards and M. Elliot, The chemistry of cooking and cleaning.

72 Richards and Elliot, The chemistry of cooking and cleaning (Boston, Witcomb and Barrows, 1907), p. 45.

73 Ibid., p. 45. Original italics.

74 J. Varty, 'On wonder'.

75 Cogdell, Eugenic design.

${ }^{76}$ See J. Varty, 'First the loaf'; 'On protein', on wheat improvement and the industrialization of flour milling.

77 See Bobrow-Strain, 'Kills a body twelve ways'.

78 Levenstein, Revolution at the table.

79 McCann, The science of eating.

$80 \mathrm{H}$. Wiley, 'Returns from the good housekeeping food and drug ballot', Good housekeeping magazine (March 1913), p. 398.

81 I. Cogswell and B. Allen, 'Bread and how to make it', Good housekeeping magazine (March 1916).

82 'Peroxide also bleaches cereals', Scientific American (August 1929), p. 183. 
83 Wiley, 'Fooling with flour', p. 118.

84 Gold Medal Flour tied itself to the movement by advertising that its white flour was never bleached, and strong popular suspicion about chemical whitening still creates a substantial market niche for unbleached bread today.

85 King, Making Americans; Jacobson, Whiteness of a different color.

86 For example, DuPuis, Nature's perfect food.

87 Tomes, The gospel of germs; A. Forty, Objects of desire.

88 Richards and Elliot, The chemistry of cooking and cleaning, p. 11.

89 T. Prudden, Dust and its dangers (New York: GP Putnam's Sons).

90 W. Hutchinson.

91 McCann, The science of eating.

92 C. Briggs 'Nutritional value of pure white flour and products', Science 63 (1926), pp. 255-7.

93 'Modern bread-baking', Scientific American (11 March 1916), p. 282.

94 For example, P. Bourdieu, Distinction: a social critique of the judgment of taste (Cambridge, Harvard University Press, 2007).

95 For an interesting critique of food safety, see G. Enticott, 'Lay immunology, local foods, and rural identity: defending unpasteurised milk in England', Sociologia ruralis 43 (2003), pp. 257-69.

96 Foucault, Society must be defended; Moore, Kosek and Pandian, Race, nature, and difference.

97 Foucault, Society must be defended. 